\title{
Mass Incarceration and the Theory of Punishment
}

\author{
Vincent Chiao
}

Version Post-print/accepted manuscript

Citation Vincent Chiao, "Mass Incarceration and the Theory of Punishment" (published version) (2015) Criminal Law and Philosophy.

Publisher's Statement This article has been reproduced with the permission of Springer International. The final publication is available at

https://doi.org/10.1007/s11572-015-9378-x

How to cite TSpace items

Always cite the published version, so the author(s) will receive recognition through services that track citation counts, e.g. Scopus. If you need to cite the page number of the author manuscript from TSpace because you cannot access the published version, then cite the TSpace version in addition to the published version using the permanent URI (handle) found on the record page.

This article was made openly accessible by $U$ of $T$ Faculty. Please tell us how this access benefits you. Your story matters. 


\title{
Mass Incarceration and the Theory of Punishment
}

\author{
Vincent Chiao ${ }^{1}$ \\ University of Toronto \\ Faculty of Law
}

NB: The final publication is available at Springer via:

http://link.springer.com/article/10.1007/s11572-015-9378-x

\begin{abstract}
An influential strain in the literature on state punishment analyzes the permissibility of punishment in exclusively deontological terms, whether in terms of an individual's rights, the state's obligation to vindicate the law, or both. I argue that we should reject a deontological theory of punishment because it cannot explain what is unjust about mass incarceration, although mass incarceration is widely considered-including by proponents of deontological theories-to be unjust. The failure of deontological theories suggests a minimum criterion of adequacy for a theory of punishment: it must take aggregation seriously such that it returns plausible results when scaled up from individual cases to large public institutions. In this vein, I briefly sketch a prioritarian metric for evaluating the use of custodial sanctions in creating and allocating social advantage.
\end{abstract}

At over 700 people in state custody per 100,000 residents, the United States incarcerates far more people than any other nation. The United States now incarcerates at a rate that is five times higher than a generation ago, and about five to 10 times higher than is the norm in other liberal societies. ${ }^{2}$ The United States incarcerates over $20 \%$ of the world's inmate population - over two million individuals-despite having less than $5 \%$ of the world's population. ${ }^{3}$ In recent years, it has become conventional to refer to the anomalously high American incarceration rates as reflecting a policy of "mass incarceration," and law, public policy and criminology journals are filled with discussions of the evils of mass incarceration, its causes and what can be done to eradicate it. ${ }^{4}$ Many

${ }^{1}$ Earlier versions were presented at a Brooklyn Law School/NYU criminal law colloquium, at the University of Toronto, St. Louis University and at a New Voices in Legal Theory workshop at Loyola Law School. I received especially helpful comments from Mitch Berman, Elizabeth Brown, Chad Flanders, Hamish Stewart, Malcolm Thorburn and Kit Wellman.

2 Steve Redburn, Jeremy Travis and Bruce Western (eds.) The Growth of Incarceration in the United States: Exploring Causes and Consequences (Washington: The National Academies Press, 2014), p. 13; see also Roy Walmsley (ed.) World Prison Population List 10th edn. (London: International Centre for Prison Studies, 2013), available at: http://images.derstandard.at/2013/11/21/prisonpopulation.pdf.

${ }^{3}$ For population figures, see United States and World Population Clock, available at http://www.census.gov/popclock/; for incarceration figures, see Walmsley, supra note 2.

4 There is by now an extensive literature across sociology, criminology, economics, history, politics and law on mass incarceration. For a brief overview of the literature on the political context in which mass incarceration developed in the United States, see Redburn, Travis, and Western, supra note 2, Chapter 4. 
commentators believe that these kinds of ultra-high incarceration rates represent a serious injustice, and that the United States should strive to reduce its inmate population by a significant degree.

The question I consider in this paper concerns the phenomenon of mass incarceration, but in a somewhat oblique way. I do not propose to ask whether the United States acts unjustly in incarcerating as many people as it does. I will assume that it does. I will also assume that a philosophical theory of punishment should, among other things, specify the conditions under which criminal punishment is just or unjust. Hence, I will assume that a philosophical theory of punishment should, when applied to the United States, contribute to explaining why the United States unjustly incarcerates too many people. The claim I defend in this paper is that, if you accept these assumptions, then you have reason to reject strictly deontological theories of punishment. This is because strictly deontological theories of punishment imply that there is nothing unjust about the number of people that are incarcerated in the United States, and would even be consistent with greatly increasing that number. There are many reasons to believe that the American criminal justice institutions are unjust. However, if you believe one of those reasons is that the United States now incarcerates too many people, then a strictly deontological theory of punishment is not for you.

The inability of strictly deontological theories of punishment to provide plausible guidance to actual criminal justice institutions on a matter of basic importance-how much punishment is enough-rests on the Nozickian principle that, when it comes to punishment, just institutions are wholly analyzable in terms of justice in individual transactions. Yet, or so I will suggest, how the criminal law allocates social costs and benefits across a population cannot cannot be analyzed purely in terms of justice in individual transactions. For a theory of punishment to provide a plausible metric for deciding how punitive a society should be requires that it look beyond individual transactions and consider the aggregate social costs of punishment, as well as how those costs could be justified to all, including those who are forced to bear them. Families, neighbors, community members, potential offenders and potential victims alike all share in these costs, and just penal institutions must be able to explain why punishing this much, and no less, is plausibly consistent with publicly avowable principles of justice. This requires a theory of punishment to at least consider the social cost of punishment, rather than rest solely on the rights of victims, or the public at large, to punish individual wrongdoers.

The argument is structured as follows. I start by briefly characterizing deontological theories of punishment. I then turn, in Section 2, to explaining why deontological theories cannot explain why mass incarceration is unjust. I consider objections in Section 3, and step back to draw broader lessons for the theory of punishment in Section 4.

1.

By a "strictly deontological theory of punishment," I mean to include any theory that (a) purports to provide an explanation of when it is permissible to punish those who commit crimes, and that (b) does so in terms that exclude the consideration of the expected costs and benefits of punishment. "Costs" and "benefits" should be understood very generically: whether in terms of utility, social resources, fundamental individual interests and so forth. I use the term "permissible" in condition (a) as follows: if it is permissible for 
A to do $\mathrm{X}$, then $\mathrm{A}$ has, in general, all the justification he needs to do X: it would not be unjust for $A$ to $X$. In particular, it would not be unjust even if the costs of doing X outweigh the benefits. If you prefer to understand "permissible" to include the logical possibility of "permissible, but unjust," then you can simply rephrase clause (a) of my definition accordingly - for instance, as: "purports to provide a comprehensive, all things considered explanation of when punishment would be justified."

What does it mean to say that strictly deontological theories categorically exclude consideration of the social costs of punishment from affecting its permissibility? It means that you can have all the justification you need to punish someone without considering whether any good would come from doing so. You may take the social costs and benefits of punishment into account if you wish, but whether you do so is strictly up to you. Hence, a strictly deontological theory does not simply insist that deontological constraints must be respected if punishment is to be just. It goes further and claims that if the constraints are respected, then punishment is just: satisfying deontological constraints is necessary and sufficient to establishing the permissibility of punishment. ${ }^{5}$

It is worth emphasizing that deontological theories are not necessarily retributive theories, and that retributive theories are not necessarily deontological theories. First, retributive theories can take a teleological form, in which retribution is simply another good to be promoted. Second, strict deontology does not necessarily require retributive reasons. For instance, Kit Wellman's strong rights forfeiture theory claims only that punishing someone who has forfeited his right not to be punished is permissible, not that we must have any particular reason to do so. It is non-committal as to what positive reasons we have to punish anyone. Therefore, a theory can be strictly deontological without being retributivist.

Of course, there are retributive forms of strict deontology as well. Deontological retributivists claim that, as Mitch Berman puts it, "punishment is justified because doing so is right-something we have reason, or ought, to do-and where its rightness is not derivative of its being valuable."6 However, this is a further commitment, not one that flows from strict deontology per se.

You may wonder who defends a strictly deontological theory of punishment. Here are four contemporary versions. First, consider Wellman's recent defense of a rights forfeiture theory. According to Wellman, whatever good punishing someone may achieve, we are only permitted to punish that person if he has forfeited his right against punishment, as normally people have a strong right not to be treated in the way that punishment inevitably treats them. A person forfeits his right not to be punished by committing a crime. Therefore, we may only permissibly punish those who have committed crimes. ${ }^{7}$ However, rights forfeiture theory is not per se a strictly deontological theory. Wellman helpfully distinguishes between "weak" and "strong" variants of rights forfeiture: the weak variant

\footnotetext{
5 So-called "hybrid" theories of punishment are not deontological theories in my sense, since these theories make satisfaction of deontological side-constraints into merely a necessary, rather than sufficient, condition for the permissibility of punishment.

${ }^{6}$ Mitchell N. Berman, "Two Kinds of Retributivism" in R. A. Duff and Stuart P. Green (eds.), Philosophical Foundations of the Criminal Law (Oxford: Oxford University Press, 2011), p. 452.
}

${ }^{7}$ Christopher H. Wellman, “The Rights Forfeiture Theory of Punishment," 122 Ethics 371 (2012). 
holds that rights forfeiture is necessary but not sufficient to explain the permissibility of punishment, whereas the strong variant holds that it is both necessary and sufficient. Rights forfeiture theory in its weak form is not a strictly deontological theory. This is because, on a weak rights forfeiture theory, it might be that we are only permitted to punish someone when she has forfeited her right against punishment and doing so also furthers some important social aim. Hence, while a weak form of rights forfeiture theory does purport to provide an explanation of the permissibility of punishment as required by (a), it need not do so in terms that exclude an assessment of the social costs of punishment, as required by (b). On the other hand, strong rights forfeiture theory-the version Wellman defends-is a strictly deontological theory. This is because it holds that rights forfeiture is sufficient to make punishment all things considered permissible, making consideration of the social costs of punishment strictly irrelevant. As Wellman puts it, if someone has forfeited her right against punishment, we may punish her whether or not doing so furthers some important social aim. ${ }^{8}$

Second, Arthur Ripstein has defended a rigorously Kantian form of strict deontology. According to Ripstein, "[u]nless the right to punish is inherent in the idea of a rightful condition, no good consequences could authorize it." Conversely, insofar as the right to punish is inherent in the idea of a rightful condition, then "its justification does not depend on those consequences." ${ }^{\prime 9}$ Ripstein is thus clearly committed to the claim that the right to punish inherent in the Kantian "rightful condition" is both necessary and sufficient to justify punishment, and that the consequences of punishment are strictly immaterial. For Ripstein, public law "constitutes a system of equal freedom in which no person is subject to the choice of another," and punishment is required to "hinder hindrances to freedom"that is, criminal acts - and even if "the incentives provided by law would be empirically unnecessary ... [punishment] would still be required." ${ }^{10}$ Indeed, on Ripstein's view, in upholding public right, the sovereign is obligated to punish every crime she comes across.

8 Ibid., p. 375 n. 7. One might speculate that Wellman's view is only meant to explain when punishment is permissible in individual contexts, rather than the permissibility of an overall institution of punishment. However, Wellman presents his account as a competitor to traditional utilitarian, retributivist, moral education, expressivist, restitutive and social safety valve theories of punishment, which clearly are attempts to justify the overall institution of punishment. Ibid., pp. 371-372. More tellingly, were rights forfeiture simply a side-constraint on individual decisions to punish someone, with the overall social institution of punishment justified by other, more consequential considerations, Wellman's theory collapses into weak rights forfeiture. This is, after all, tantamount to claiming that guilt is a necessary constraint on punishment, but that punishment is in general only permissible when it furthers some valuable social aim. But Wellman expressly denies this claim in his defense of strong rights forfeiture theory. Ibid., p. 375. All that being said, there is an interesting question as to whether strong rights forfeiture theory is consistent with the approach to punishment he defended in an earlier paper, in which he seemed to insist that state punishment must further a valuable social aim (inter alia, deterring crime) if it is to be justified. See Christopher H. Wellman, "Rights and State Punishment," Journal of Philosophy 106(8) (2009): pp. 419-439, especially 428-430.

${ }_{9}^{9}$ Arthur Ripstein, Force and Freedom: Kant's Legal and Political Philosophy (Cambridge: Harvard University Press, 2009), p. 301.

10 Ibid., pp. 306-307. 
Failing to punish is "strictly speaking inconsistent with the rightful condition," and hence would be "wrong in the highest degree," and even "a single exception" would be a renunciation of the law's own principle. ${ }^{11}$

Third, although Alan Brudner ultimately rejects Ripstein's Kantian approach, Brudner's own Hegelian theory is itself a form of strict deontological theory. Brudner explicitly denies that punishment can be "justified in prospective terms as a means to furthering socially desirable ends." 12 He rejects a Hartian-style mixed theory, according to which socially beneficial consequences of punishment provide the affirmative reason in favor of punishment; the "beneficial effects of punishment" cannot be regarded, Brudner claims, as a public reason in favor of punishment and hence they are of no justificatory significance. ${ }^{13}$ On Brudner's view, a criminal renders himself vulnerable to punishment because by intentionally denying someone else's rights he implicitly denies his own, and as a result he has no basis for complaint when the state violates his rights by punishing him. ${ }^{14}$ The substantive justification for state punishment, according to Brudner, is that it is required to make manifest that the criminal's implicit claim to an unlimited liberty of action is "aporetic," and thereby "to vindicate the truth ... that the only valid claims of permission to act are those that can be validated by equal ends." 15 On Brudner's view, actual concrete punishment is required to make this manifest precisely because, by actualizing his claim to unlimited freedom in external conduct, the criminal clothes this egoistic principle in a false veneer of legal validity. Far from being a means of promoting the public good, punishment is justified because it expressively denies the wrongdoer's own denial of rights. Hence, Brudner's view is a strictly deontological theory: it holds that punishment is permissibleindeed, required-under conditions that make no mention of punishment's contribution to public welfare, but that instead turn only on the expressive vindication of rights.

Finally, and perhaps surprisingly, Antony Duff has recently defended a form of retributive theory that implies strict deontology. ${ }^{16}$ According to Duff, "what gives criminal punishment its meaning and the core of its normative justification is its relationship, not to

${ }^{11}$ Ibid., pp. 320-321. To be fair, Ripstein attempts to constrain the maximalist tendencies of his Kantian view by insisting that he is not taking "any specific position about what public resources should be devoted to crime detection, or where those resources should be focused." However, it is hard to see what motivates the distinction between investigation (entirely discretionary) and prosecution (entirely mandatory): if it is such an affront to the law to allow even a single crime to go unpunished, why is it not equally an affront if crime that could easily be detected and punished were allowed to go undetected and unpunished? Perversely, this suggests that the state could decide to underfund policing and crime detection precisely so that it could avoid acquiring the rigorous Kantian duty to punish criminals once detected. Ibid., p. 321.

12 See Alan Brudner, Punishment and Freedom (Oxford: Oxford University Press, 2008), p. 38.

13 Ibid., p. 42.

14 Ibid., pp. 37-41. Unlike Wellman, Brudner views punishment as a rights violation rather than as a rights forfeiture.

15 Ibid., p. 46.

16 R. A. Duff, "Retrieving Retributivism," in Mark White (ed.), Retributivism: Essays on Theory and Policy (Oxford: Oxford University Press, 2011). 
any contingent future benefits that it might bring, but to the past crime for which it is imposed." This, according to Duff, is the "core retributivist thought." 17 Just as individuals have standing to call friends, family, colleagues to account in the case of ordinary transgressions, the political community has standing to call citizens to account in the case of public wrongs. Calling those who commit public wrongs to account is not done because it furthers other goals that we might have; rather, it is constitutive of the respect due to citizens. Failure to pursue and prosecute a wrongdoer betrays an attitude of indifference to the victim, and perhaps to the perpetrator as well. Criminal punishment is a way for the community and wrongdoer to show that they are appropriately engaged with the victim's injury via the means of a "formal, forceful expression of apology."18 Showing respect for the agency of the victim justifies us in calling the wrongdoer to account through punishment, and this reason for punishment is categorically insensitive to the expected social cost of punishment. Hence, insofar as calling a wrongdoer to account provides a sufficient reason for punishing someone-which it must, since it is allegedly constitutive of showing respect, something we presumably have sufficient reason to do-it follows that Duff's retributivism is strictly deontological.

In contrast to Wellman's non-committal form of strict deontology, Ripstein's, Brudner's and Duff's theories are both strictly deontological and retributive. They go beyond the claim that punishment is only permissible when someone has forfeited his or her rights, but insist that there is a positive retributive requirement to punish: to uphold the rightful condition, to expressively deny the denial of rights or to show respect for those whose rights were invaded by wrongdoing. Insofar as calling a wrongdoer to account through the criminal law is constitutive of showing respect to our co-citizens, then failing to do so betrays an indifference to the victim, and may even reflect a callous indifference to the wrongdoer himself. ${ }^{19}$ Strictly deontological retributivism would not allow us to tell one victim that we are not going to devote the resources to investigating, prosecuting and punishing the person who assaulted him because we have a better use for those resources. Even if we do have a "better" use for the resources, to fail to call his assailant to account just is to fail to show him sufficient respect-that is what it means for punishment to be constitutive of respect for the victim. Surely it is not the case that we are permitted to respect some victims less than others simply because there are more of them. If we design our institutions such that we know in advance that a great many perpetrators-indeed, with respect to some crimes, the large majority of them-will never be called to account for their crimes, then victims of unpunished crimes have a powerful deontological claim that they are not being taken sufficiently seriously. Their objection remains even if people who are at risk of becoming unemployed, sick or unable to access a tolerably good education

\footnotetext{
${ }^{17}$ Ibid., p. 3. Or, as Nozick once put the point, the consequential goods achieved by punishing wrongdoers-reform, deterrence or incapacitation, say-are merely an "especially desirable and valuable bonus" and are not "part of a necessary condition for justly imposed punishment." Robert Nozick, Philosophical Explanations (Cambridge: Belknap Press, 1981), p. 374.
}

18 This sentence is a paraphrase of supra note 16, pp. 16-18.

${ }^{19}$ Supra note 16, p. 14. 
would also have claims if resources were diverted from those programs to fund a fully enforced criminal justice regime. ${ }^{20}$

2.

The gist of the argument can be presented as follows:

1. The United States today unjustly incarcerates too many people.

2. According to a strictly deontological theory, punishment is just (i.e., permissible all things considered) if it does not violate relevant deontological constraints.

3. The current American incarceration rate is not the result of systematic violation of deontological constraints.

4. Hence, a deontological theory of punishment cannot explain why the United States unjustly incarcerates too many people.

Note that I am simply assuming that (1) is true. Since I do not attempt to defend this assumption, my argument will only be appealing to those who are already inclined to believe that (1) is true, or that it at least might be true. However, since many, perhaps most, informed commentators on American criminal justice believe that the United States does indeed unjustly incarcerate too many people, I suspect that assumption (1) will not be too contentious. The second step of the argument flows from the logical structure of a deontological theory of punishment. Step (3) requires more elaboration, and I will focus most of my attention on it.

First, however, I pause to clarify the nature of premise (1). To be sure, the argument would be more ambitious if it were stated unconditionally, i.e., if it purported to show that some specified rate of incarceration, $n$, is necessarily unjust, unjust in all possible worlds. However, I doubt any such claim can be sustained, at least for any plausible value of $n^{21}$ This is because for any plausible value of $n$, whether it is just to incarcerate that many people depends on a wide range of social facts: what might be an unjustly high rate of incarceration in modern Sweden might not be unjust in post-revolutionary China, or even in the contemporary United States. To put it slightly differently, consider a theory of punishment as a function that takes a range of factors (crime rates, proportionality, legal traditions, etc.) as inputs and returns an estimate of the maximum permissible rate of

20 Doug Husak has objected that we should not try to distinguish between equally guilty individuals, and hence that it is a strength rather than a weakness of deontological theories that they support equal punishment for all the guilty. But, if that is true, then punishment maximalism follows directly. This objection also depends on construing fairness to require equal ex post punishments rather than equal ex ante chances, a point I have investigated elsewhere. See Vincent Chiao, "Ex Ante Fairness in Criminal Law and Procedure," New Criminal Law Review 15(2) (2012): pp. 27 7-332.

21 What is a plausible value of $n$ ? It is worth bearing mind that even in the United States today the incarceration rate is less than 1\%, and that in most other Anglophone countries, the rate is closer to $0.01 \%$. It is hard to imagine what a society that incarcerated, say, $10 \%$ or $20 \%$ or $30 \%$ of its population would look like, and it may well be the case that under social conditions where one would find such a rate-perhaps conditions of civil war or insurrection-normal theories of justice would simply fail to apply. 
incarceration as an output. Call that estimate $n_{\text {MAx }}$. No theory of punishment treats $n_{\text {MAx }}$ as a constant, regardless of what values are assigned to the relevant inputs. The question, however, is which inputs a theory treats as relevant. The assumption I am making is that a plausible theory of punishment should return an estimate for $n_{\text {MAX }}$, for the United States today, that is lower than $0.75 \%$. Yet the very limited range of inputs that a strictly deontological theory treats as relevant means that it will return an estimate of $n_{\mathrm{MAX}}$ for the contemporary United States that exceeds $0.75 \%$. As a result, it cannot explain why the United States today unjustly incarcerates too many people.22

Theories of punishment that are at least open to consequential considerations can appeal to a range of aggregative inputs in estimating $n_{\text {MAx }}$. They can, for instance, consider the expected aggregate costs of incarceration-the harms imposed directly on those incarcerated, the collateral consequences on families and communities, and the opportunity costs to society of time wasted languishing in prison-as well as its expected benefits, such as the reduction in criminal offending and the vindication of the rights of victims. If it is the case that the marginal benefits from incarceration are declining, then a theory that is open to aggregative reasons could set $n_{\mathrm{MAX}}$ at a point where further reliance on incarceration entails more harm than good. An interpretation of $n_{\text {MAx }}$ along these lines could provide a plausible explanation of why the United States unjustly incarcerates too many people if there is reason to believe that, in expanding its custodial population from approximately 120 per 100,000 to over 700 per 100,000 , the United States has come to incarcerate so many people that the marginal cost of incarceration outweighs its marginal benefits. Insofar as the evidence supports this proposition, a theory of punishment that is at least open to aggregative reasons could explain why it is that the United States unjustly incarcerates too many people.

Of course, it would be question-begging to baldly complain that a strictly deontological theory does not take into account the expected consequences of punishment. That is simply the nature of a strictly deontological theory. The difficulty, however, is rather different. It is that a theory that is sensitive to the social cost of punishment can explain why it is the case that the United States now incarcerates too many people, whereas one cannot construct a parallel explanation in strictly deontological terms. Hence, insofar as a theory of punishment is meant to provide plausible guidance in evaluating large, penal institutions, there is prima facie reason to reject a strictly deontological theory.

Strictly deontological theories rely exclusively on individualistic reasons: reasons grounded in the nature of a specific individual's conduct. On a strictly deontological theory,

\footnotetext{
22 To illustrate, consider the following simplified example. Suppose your theory of punishment says that the single input factor that is relevant to determining whether punishment is permissible is guilt: if someone is guilty of a crime, then it is permissible to punish him. Suppose, further, that in society $\mathrm{S}$ there is only one crime, $\mathrm{C}$, and people who are convicted of committing $\mathrm{C}$ invariably serve one year in prison. In this case, the value of $n_{\operatorname{MAx}}$ is straightforwardly estimated: it is simply the number of people who commit $\mathrm{C}$ in a given year. After all, if the state were to investigate, prosecute and convict every single person who commits $C$, then the number of instances in which $C$ is committed would determine the actual incarceration rate, and given that time served for $\mathrm{C}$ is one year, at any given time $n_{\mathrm{MAX}}$ should correspond to the number of instances of $\mathrm{C}$ in the previous 364 days. Any higher rate of incarceration, and $S$ would inevitably be incarcerating innocents. Because $n_{\text {MAX }}$ is a ceiling, any lower rate of incarceration of C-offenders would necessarily be permissible.
} 
we have an equally compelling reason—or an equally valid permission-for punishing any person who exhibits those features, whether he is the first or the $n^{\text {th }}$ person to do so, for any arbitrarily large value of $n$. Hence, insofar as a deontological theory purports to show that it is permissible to punish any criminal wrongdoer, it necessarily shows that it is permissible to punish all of them, regardless of the costs of doing so. Punishing that many people may be pointless, or even counterproductive, from the point of view of the public good. But deontological theories are united in rejecting those types of concerns from bearing on the permissibility of punishment: they tell us that we are permitted to punish regardless of whether doing so "is necessary to promote some important aim." 23 Hence, for a strictly deontological theory to explain why the United States today incarcerates too many people, it must draw on an allegedly widespread violation of a relevant deontological constraint as explaining America's mass levels of incarceration. The paradigmatic deontological constraints on punishment are that punishment be restricted to people who are actually guilty of true crimes, and be administered in proportion to their culpability, which together imply that $n_{\mathrm{MAX}}$ would not be exceeded so long as everyone who is incarcerated is guilty of a crime that merits incarceration. So a strictly deontological theory must seek to explain American incarceration rates via systematic punishment of the innocent, overcriminalization and/or disproportionately harsh punishment.

Is it the case that the American incarceration rate is so anomalously high because of a systematic violation of one of the paradigmatic deontological constraints on punishment? There is reason to be skeptical. Recent empirical work on the causes of mass incarceration in the United States suggests that the standard set of deontological constraints on punishment do not explain why the United States incarcerates as many people as it does. Indeed, there is reason to believe that the United States could actually incarcerate many more people than it currently does while fully respecting all of these constraints.

\section{(a) Factual Guilt}

I start with the proposition that only those who are actually guilty of a crime should be punished. Suppose the United States were to fully respect this constraint, or at least as well as can reasonably be expected since some errors will be inevitable. Would this contribute to keeping the incarceration rate below mass levels? No. In fact, the United States could dramatically raise incarceration rates while fully respecting the constraint against punishing the innocent. The reason is simple. A profoundly important fact about criminal justice in the United States is that, even with the highest incarceration rate in the world, and even with respect to so-called "core" offenses like assault, sexual assault, theft and burglary, the criminal law in the United States is not even remotely close to being fully enforced. In 2007, roughly $61 \%$ of murders and non-negligent manslaughters known to police resulted in arrests or were otherwise considered "solved." Those rates go down substantially for other crimes: comparable figures for rape are $42 \%$, for robbery $26 \%$ and for burglary and car theft $13 \% .{ }^{24}$ Considered in the aggregate, clearance rates for violent

\footnotetext{
${ }^{23}$ Supra note 7, p. 375 n. 7.

24 Sourcebook of Criminal Justice Statistics Online, Table 4.19.2007: Offenses known to police and percent cleared by arrest, available at: http://www.albany.edu/sourcebook/pdf/t4192007.pdf.
} 
crime have hovered around $45 \%$ for several decades, and the comparable figure for property crimes is roughly $15 \% .{ }^{25}$ These are, moreover, clearance rates, not conviction rates-that is, they represent the rate at which police consider a crime "solved," not the rate at which someone has actually been called to account for the crime through prosecution and punishment. Turning to convictions, in state courts in 2004, approximately $68 \%$ of murder and non-negligent manslaughter arrests resulted in convictions, while only about $16 \%$ of motor vehicle theft arrests and $44 \%$ of burglary arrests resulted in convictions. ${ }^{26}$

As a rough, back-of-the-envelope calculation, these figures together suggest that about $43 \%$ of murders and non-negligent manslaughters, $6 \%$ of burglaries and $2 \%$ of motor vehicle thefts ultimately resulted in convictions. These figures are concededly rough, since they do not account for people who are convicted through process commencing with a summons rather than an arrest, nor do they account for crimes that are considered cleared but that do not result in an arrest. On the other hand, these rates are sensitive only to crimes known to police, and there is a wealth of evidence that a great deal of crime goes unreported-in some categories, such as assault (65\%), sexual assault (86\%) and domestic violence (90\%), a majority to an overwhelming majority of crime is not reported. ${ }^{27}$ These figures are not anomalous: they are consistent with contemporary and historical trends in England. 28

In short: there are many more instances of people forfeiting their rights against criminal punishment by committing crimes than there are instances of criminal punishment actually being imposed. The very high rate of attrition between the rate at which crimes are committed and the rates at which they are punished suggests that there is quite an extensive degree of headroom in criminal justice inputs before the constraint of factual guilt would kick in as a limiting factor. For instance, if my back of the envelope calculations are any guide, American criminal justice institutions could prosecute 10 times as many domestic assaults, 16 times as many burglaries and fully 50 times as many car thefts while still punishing only the guilty.

\section{(b) Criminalization}

\footnotetext{
25 Sourcebook of Criminal Justice Statistics Online, Table 4.21.2007: Percent of offenders known to police who were cleared by arrest, available at: http://www.albany.edu/sourcebook/pdf/t4212007.pdf.

${ }^{26}$ Sourcebook of Criminal Justice Statistics Online, Table 5.0002.2004: Felony convictions and sentences and rate per 100 arrests, available at: http://www.albany.edu/sourcebook/pdf/t500022004.pdf.

27 See David Kennedy, Deterrence and Crime Prevention: Reconsidering the Prospect of Sanction (London: Routledge, 2009), p. 45.

28 See Andrew Ashworth and Mike Redmayne, The Criminal Process 4th edn. (Oxford: Oxford University Press, 2010), pp. 156-157 (estimating that "no more than 2 percent" of the eight most frequently committed offenses in the United Kingdom result in a conviction). For historical evidence, see Peter King, Crime, Justice, and Discretion in England 1740-1820 (Oxford: Oxford University Press, 2005), pp. 11-12, 132-134 (reporting estimates from the late $18^{\text {th }}$ and early $19^{\text {th }}$ centuries that only $1 \%$ to $10 \%$ of property crimes were prosecuted).
} 
Deontological theories of punishment do not simply claim that it is right (or all things considered permissible) for the guilty to be punished proportionately. They also typically claim that what it is to be guilty is, within some range, not purely a matter of positive law. People do not forfeit their rights or deserve punishment simply because the legislature says they do. Rather, they forfeit their rights or deserve punishment when the acts they perform are appropriately or rightly criminalized. Thus, even if it is conceded that the United States is mostly punishing guilty people, perhaps the United States has criminalized conduct that it is simply inappropriate to criminalize in the first place, which in turn explains why the United States incarcerates too many people. ${ }^{29}$

By far the most significant area of criminal law that might plausibly be thought of in these terms is the so-called "war on drugs." Indeed, it is sometimes claimed that the war on drugs explains America's experiment with mass incarceration..$^{30}$ If this claim were true, and if a convincing case could be made that criminalizing narcotics violates some deontological constraint on criminalization, then perhaps deontological theorists would be able to explain why, even accounting for the massive headroom in criminal justice inputs implied by a strictly deontological theory, the United States should have a much lower incarceration rate. Such theorists could claim that while there would be no injustice in prosecuting literally every instance of every crime, it turns out there are many fewer such instances than we thought, especially once we take into account the malign influence of the war on drugs.

Unfortunately, the claim that the war on drugs explains the ultra-high American incarceration rate is unsupported by the evidence. For over two decades, the percentage of people imprisoned for a drug offense in the United States has been fairly stable at about $20 \%$ - significant, but not enough to explain the five-fold increase in incarceration rates over the last generation. ${ }^{31}$ The majority of people in state prisons are there because they committed violent crimes; in fact, there are about as many people in state prisons for homicide ( $14 \%$ of state inmates) as there are for drug offenses $(16 \%)$. If we factor in property offenses, nearly three quarters (72.6\%) of state prisoners are in custody because

\footnotetext{
29 The unstated empirical hypothesis is that increasing criminalization causes increasing incarceration. There is reason to doubt this hypothesis. After all, the set of crimes for which people are actually sent to prison has remained fairly stable even as incarceration rates exploded. The growth in incarceration has largely been driven by increased numbers of prosecutions for a relatively small number of crimes. It is not the case that criminalizing $X$ automatically results in any, much less many, prosecutions for X. My thanks to Elizabeth Brown for drawing my attention to this fact.

30 See, e.g., Michelle Alexander, The New Jim Crow (New York: The New Press, 2010).

31 In 2012, drug offenders made up approximately $16 \%$ of the state prison population. E. Ann Carson, Prisoners in 2013 (Washington: Bureau of Justice Statistics, 2013), p. 15, tbl. 13, available at: http://www.bjs.gov/content/pub/pdf/p13.pdf [hereinafter Carson, Prisoners]; see also John F. Pfaff, "The War on Drugs and Prison Growth: Limited Importance, Limited Legislative Options," Harvard Journal on Legislation (forthcoming 2015) [hereinafter Pfaff, War]; James Forman, Jr., "Racial Critiques of Mass Incarceration: Beyond the New Jim Crow," 87 N.Y.U. Law Review (2012): pp. 47-48.
} 
of traditional mala in se offenses. ${ }^{32}$ While it is true that stripping out people convicted of drug crimes would lower incarceration rates, it would not bring rates anywhere near what they were for most of the $20^{\text {th }}$ century, or as low as they are in any of America's usual comparator countries. Although there was indeed a sharp increase in the proportion of people incarcerated for drug offenses during the 1980s, that was a sharp increase from a very low baseline: in 1980, state prisons housed only 19,000 drug offenders, compared to over 170,000 violent offenders and nearly 90,000 property offenders. By 2009 , the number of drug offenders in state prisons grew by roughly an additional 220,000 people, but the number of violent offenders grew by over 500,000 and the number of property offenders by almost $172,000 .{ }^{33}$ In fact, over half of the growth in prison populations from 1980 to 2009 is explained by growth in the number of incarcerated violent offenders, and if we factor in property offenses, we account for fully two thirds of the growth. ${ }^{34}$ As John Pfaff has noted, "[e]ven if we released every offender currently serving time for a drug conviction, the US prison population would remain above 1 million, and the racial composition of its prisons would not shift much" - specifically, the prison population would go from 1.4 million to 1.1 million, and the percentage of black prisoners would decline two percentage points, to $36 \%$. $^{35}$

This is not to say that the so-called "war on drugs" is morally insignificant, or that it has not wrought huge swaths of largely pointless devastation through the lives of a great many people. It would also be overstating the case to say that the war on drugs has had a negligible impact on American incarceration rates. It is, for instance, possible that drug offenses may matter to incarceration rates more indirectly: it may be that the war on drugs has a given large number of people criminal records, resulting in longer sentences for subsequent, non-drug offenses. Or it is possible that the war on drugs has made drug

\footnotetext{
32 Carson, Prisoners, supra note 31, p. 15, tbl. 13. The Marshall Project, a news organization focused on criminal justice issues in the United States, has put the Bureau of Justice Statistics online in the form of an interactive set of sliders, which the reader can manipulate to see how many violent offenders would have to be released in order to cut America's incarceration rate by $50 \%$. Note that a $50 \%$ reduction would still leave the United States as the most punitive developed country on the planet. Available at: https://www.themarshallproject.org/2015/03/04/how-to-cut-the-prisonpopulation-by-50-percent.
}

33 Pfaff, War, supra note 31, tbl. 1A.

34 See John F. Pfaff, "Escaping from the Standard Story," Federal Sentencing Report 26 (2014): pp. 265-266.

35 John F. Pfaff, "The Micro and Macro Causes of Prison Growth," Georgia State University Law Review 28, p. 1270; John F. Pfaff, "The Causes of Growth in Prison Admissions and Populations," Working Paper No. 1884671 (2011), available at:

http://papers.ssrn.com/sol3/papers.cfm?abstract_id=1884674 [hereinafter Pfaff, Causes of Growth], pp.22-24. Even Blumstein and Beck acknowledge that drug offenses do not explain the bulk of the explosion in incarceration rates. Alfred Blumstein and Allen J. Beck, "Reentry as a Transient State between Liberty and Recommitment" in Jeremy Travis and Christy Visher (eds.), Prisoner Reentry and Crime in America (Cambridge: Cambridge University Press, 2005), pp. 50, 78 [hereinafter Blumstein and Beck, Transient]. But see Alfred Blumstein and Allen J. Beck, "Population Growth in U.S. Prisons, 1980-1996," in Michael Tonry and Joan Petersila (eds.), Prisons (Chicago: University of Chicago Press, 1999), pp. 17, 21 [hereinafter Blumstein and Beck, Population Growth]. 
markets more dangerous, and hence more criminogenic. But in terms of actual drug incarcerations, it is reasonably clear that they contribute a non-negligible but still relatively small amount to current prison populations, and that their impact on the incarceration rate is far overshadowed by the impact of people serving time for traditional "core" crimes, violent crime in particular.

\section{(c) Proportionality}

Finally, it might be thought that it is American criminal justice institutions' proclivity for meting out extraordinarily excessive sentences that explains why its custodial population is so large. That American sentences are longer than they are in other parts of the world is reasonably clear; that they are therefore disproportionate is less so. ${ }^{36}$ There are, of course, many instances of headline-grabbing sentences that many people believe to be disproportionate, perhaps even for serious crimes. However, these kinds of ultra-harsh sentences turn out to be largely immaterial to the aggregate incarceration rate. What appears to be doing most of the work is an increased willingness on the part of American prosecutors to file felony charges which carry some prison time, not a demand for extremely long sentences in the typical case. ${ }^{37}$

In recent work, Pfaff has analyzed data from 11 states from the National Corrections Reporting Program from 1982-2003, and found that, when examining median and $75^{\text {th }}$ percentile prisoners, time served has actually been stable or in some cases even declining in this period. ${ }^{38}$ Median time served ranged from about six months (California) to about two years (New Jersey); at the $75^{\text {th }}$ percentile, time served ranged from about one year (California) to about four (Virginia). In a subsequent paper, Pfaff bolsters this conclusion with data drawn from all 50 states. Actual release rates from state prisons over the last three decades closely parallel a hypothetical invariant release schedule, according to which half of all prisoners are released within a year, and three quarters within five years, with only $1 \%$ remaining incarcerated after 11 years. For most inmates, the amount of time served has not materially increased during the last three decades, even as the incarceration rate has shot up. ${ }^{39}$

36 See, e.g., James Q. Whitman, Harsh Justice: Criminal Punishment and the Widening Divide between America and Europe (Oxford: Oxford University Press, 2005), especially Chapter 2.

37 Bureau of Justice Statistics report that, for prisoners released in 2012, the median time served for violent crimes was 28 months, 12 months for property crimes and 13 months for drug offenses. See Carson, Prisoners, supra note 31, p. 18 tbl. 17.

38 John F. Pfaff, "The Myths and Realities of Correctional Severity," 13 American Law and Economics Review 491 (2011): pp. 499-504 [hereinafter Pfaff, Myths]. The states in question are California, Colorado, Illinois, Kentucky, Michigan, Minnesota, Nebraska, New Jersey, South Dakota, Virginia and Washington.

39 Pfaff, Causes of Growth, supra note 35, pp. 30-32. As Pfaff puts it, "sanctioning severity does not appear to have changed much at all between 1977 and the early 2000s; to the extent that there has been any change since then, it has been in the direction of leniency." Ibid., p. 4. For contrary views, see Blumstein and Beck, Population Growth, supra note 35, and Blumstein and Beck, Transient, supra note 35. Pfaff's findings are based on two datasets, not utilized by other studies, that allow Pfaff to disaggregate prison admissions per arrest into its component parts, namely felony filings 
It is perhaps worth noting that, while many states have ultra-harsh repeat offender laws, with the exception of California, they appear to be rarely used. ${ }^{40}$ Prosecutorial discretion generally means that there are ways around most harsh sentencing laws. Indeed, since the way around them may often be through a guilty plea to a lower sentence, it is possible that what these laws do is to enhance the ability of prosecutors to efficiently send guilty people to prison rather than ramp up time served-an outcome to which strictly deontological theories can hardly object.

Indeed, while time served has been relatively flat, Pfaff presents evidence which points to an increase in the rate at which prosecutors file felony charges, rather than arrest rates, conviction rates, or harsher sentencing, as the more significant contributor to prison population growth in the United States. Since the increase in felony charges presumably comes from cases prosecutors would in previous generations have dismissed or treated as misdemeanors, it appears that, as Pfaff puts it, "despite the attention paid to three-strike laws, TIS [truth in sentencing laws], and the like, the predominant locus of increased punitiveness over the past ten to fifteen years still appears to be at the low end, not the high." 41 This suggests in turn that a jurisdiction that does not utilize extraordinarily harsh sentencing outcomes as a general matter may still incarcerate an extraordinary number of people largely in virtue of growth in its custodial inputs-a source of growth that, as we have seen, deontological theories are unable to meaningfully limit. It is, Pfaff writes, "[c]hanging decisions in prosecutors' offices about when to file charges" that "appear to be the primary-at times, seemingly almost the sole-driver of prison growth, at least since the mid- to late-1980s." 42

Earlier studies have found a similar pattern from the 1970s to 1988, suggesting that, even as America's experiment with mass incarceration was ramping up, time served was actually going down slightly, but was more than compensated for by an increase in prison admissions. ${ }^{43}$ This should not be a surprising finding. The very low rate at which crimes are prosecuted implies that incarceration rates are dramatically more sensitive to prosecutorial decisions than they are to crime rates. Suppose, for instance, that one out of 10 criminals is prosecuted. Even a modest 5\% increase in the prosecution rate would result in a $50 \%$ increase in indictments. In contrast, since only one out of 10 cases is being prosecuted to begin with, a $5 \%$ rise in the crime rate would be barely noticeable, with only

per arrest, convictions per filing and prison admissions per conviction. Pfaff, Causes of Growth, supra note 35 , pp. 5-7.

${ }^{40}$ Franklin Zimring, Gordon Hawkins, and Sam Kamin, Punishment and Democracy: Three Strikes in California (Oxford: Oxford University Press, 2001), pp. 20-21. As Zimring has noted elsewhere, the federal "three strikes" law was applied 35 times in the four years after its enactment, whereas the California statute-enacted the same year as the federal statute-was applied over 40,000 times. Indeed, the California statute "has resulted in nine times as many prison terms as all of the 26 other three strikes laws in the United States combined." Franklin Zimring, "Imprisonment and the New Politics of Criminal Punishment," Punishment \& Society 3 (2001): p. 163.

41 Pfaff, Myths, supra note 38, p. 504.

42 Pfaff, Causes of Growth, supra note 35, pp. 7-21.

${ }^{43}$ Patrick Langan, “America's Soaring Prison Population,” Science 251 (1991): p. 1568. 
a $0.5 \%$ impact on indictments. The institutional structure of the criminal law, with persistently low rates of prosecution relative to crime, means that prosecutorial charging decisions inevitably will have a disproportionately large effect on the rate of inputs into the criminal justice system. ${ }^{44}$

To summarize: holding crime rates constant, the United States could dramatically raise the rate at which people are placed into the criminal justice system without running afoul of the deontological constraint against punishing the innocent. Moreover, even if the United States refused to incarcerate people for drug crimes, its incarceration rate would still be anomalously high, since the large majority of people who are in custody are there for traditional mala in se crimes. Finally, ultra-harsh sentences do not explain why the American incarceration rate is as high as it is. To the contrary, there is some reason to believe that the major cause of growth in the American incarceration rate is that more people who commit crimes are going to jail for doing so. Hence, I conclude that a prima facie case in favor of (3) - that the current American incarceration rate is not the result of systematic violation of deontological constraints - is made out. It follows that there is a prima facie case that a strictly deontological theory cannot explain why the United States now incarcerates too many people.

I stress that I am not criticizing deontological theories of punishment for being unable to resolve the type of highly concrete, fine-grained "policy" question that philosophical theories in general should not be expected to answer. What I am criticizing them for is their inability to get a grip on one of the most basic, and most pressing, issues in criminal justice, which is how much of it there should be. A theory of punishment that cannot provide a plausible framework for deciding whether it would be a good idea to quintuple the size of the incarcerated population in the space of a generation does not have an incomplete account of how much criminal punishment is enough; it is one that has no such account. That is a serious failing in a theory that is ostensibly meant to help us evaluate actual criminal justice institutions.

3.

I now turn to consider four objections.

First, one might object that even a relatively short custodial sentence of a few months could be disproportionate for the crimes that the people who receive those sentences are guilty of. The difficulty with this line of objection is two-fold. First, while the concept of proportionality could, of course, be modulated so as to hit an exogenously specified incarceration rate, this would drain proportionality of any independent content. It would simply be a means for ensuring that the incarceration rate doesn't exceed some arbitrarily specified value for $n_{\text {MAx }}$, rather than a substantive factor in determining what that value should be. Second, once we leave behind the realm of the outrageous-boiling oil for bicycle thieves, as Philip Pettit and John Braithwaite once put it-what is a proportionate punishment is very hard, if not impossible, to specify concretely. Indeed, deontological theorists themselves concede as much. For instance, while Wellman insists that a person who commits a crime only forfeits his claim against a proportionate punishment, he is at

\footnotetext{
${ }^{44}$ See King, supra note 28, p. 12.
} 
pains to note that what specifically is required for a punishment to be proportionate is very hard to determine. As he notes, "the most sophisticated retributivists routinely shy away from offering precise punishments for specific crimes," and he too declines to offer a "simple formula for determining which specific rights are forfeited by any given crime." 45

I do not mean to suggest that proportionality is a meaningless ideal. My claim is rather that the ideal of proportionality in punishment is, to borrow a Rawlsian slogan, "political, not metaphysical." 46 The norm of proportionality is made meaningful by the decisions of appropriately constituted institutions, not by abstract moral reflection. We have considered judgments - for instance, that life imprisonment for petty theft is wrong-and these judgments provide a reasonably solid basis for judging a sentencing regime that routinely produces those kinds of outcomes to be in that respect unjust. But within these very broad limits, what proportional punishment consists in is determined by the operation of appropriately constituted institutions, institutions that may be informed by particular cultural beliefs, legal traditions and so forth. If we are unsure about the sentences our institutions generate, we have reason to take a hard look at the design of those institutions to ensure that they are not dominated by perverse incentives, capture and short-term political gain. It may still be the case that the sentences they generate are pointlessly long, inflicting more harm than benefit. But they will not, therefore, be disproportionate.

Second, proponents of strictly deontological theories of punishment may bite the bullet, reject premise (1), and claim that mass incarceration is permissible, at least under some circumstances. Suppose, for instance, that half of the population steals a kidney from the other half of the population, and that all of the kidney thieves are promptly captured, prosecuted and imprisoned for a few months. What would be the injustice in that? After all, everyone in prison is guilty, and is serving a proportionate punishment. Isn't that exactly what punishment is for? ${ }^{47}$

Here, it is important to recall that I am not purporting to show that a strictly deontological theory of punishment is false, nor even that incarcerating large numbers of people is necessarily impermissible. I am only purporting to show that if it is true that the United States currently incarcerates too many people, then you should reject a strictly deontological theory of punishment.

I will not try to convince you that incarcerating half of the population would be unjust, even if they have all committed a crime. I will limit myself to pointing out that if it isn't, then obviously incarcerating $0.75 \%$ of the population - the current American rate -is also just, given that almost everyone incarcerated is in fact guilty of a crime. This implies that you should be unmoved by the thought that the American incarceration rate is five times higher now than it was a generation ago, and that it has increased even in the face of

\footnotetext{
45 Supra note 7, pp. 386-387.

${ }^{46}$ See Emmanuel Melissaris, "Toward a Political Theory of the Criminal Law: A Critical Rawlsian Account," New Criminal Law Review 15 (2012): pp. 146-148. Metaphysical conceptions of proportionality remain current in the literature; see e.g., Greg Roebuck and David Wood, "A Retributive Argument against Punishment," Criminal Law and Philosophy 5 (2011): pp. 73-86.

${ }^{47}$ I owe this example (and this objection) to Kit Wellman.
} 
steadily decreasing crime rates. Moreover, if you think that it is a good thing that those who commit crimes are imprisoned, then you should bemoan the fact that in recent years American incarceration rates appear to have leveled off or even declined somewhat from their peak, and advocate a return to the halcyon days of staggering growth in the rate at which criminals were sent to prison. Rather than worry about the fact that America's incarceration rate is dramatically higher than the rate in any other similarly developed nation, you should hold it out as a model for other countries to emulate. Perhaps these views are sound; certainly, nothing I have argued is meant to show that they are not. But if you are doubtful, then you should not bite the bullet. You should reject the premise of the kidney example, and you should conclude that guilt alone does not provide a sufficient reason to incarcerate an arbitrarily large percentage of the population.

Third, it might be argued that my account has wrongly portrayed deontological punishment theorists as oddly single minded-obsessed with punishing the guilty to the exclusion of all else. But nothing prevents strict deontological theorists from recognizing value pluralism, such that any deontological reason we have to punish is qualified by the many competing demands that citizens can legitimately make on each other. Thus, Wellman points out that rights forfeiture is not always sufficient to render punishment permissible, "because there may be other factors which ground obligations." 48 For instance, if $A$ has promised $B$ that she will not punish $C$ even if $C$ does forfeit his rights, then it would not normally be permissible for $A$ to punish $C$ in the case that he does forfeit them.

In considering this objection, it is worth bearing in mind that strictly deontological theories of punishment are, or so I claim, unable to articulate a plausible target for social levels of punishment precisely because they deny value pluralism: they do not merely claim that there is $a$ deontological aspect to justified punishment, but insist that satisfying the relevant set of deontological constraints is all there is to justified punishment. For instance, showing that Jones has forfeited his right not to be punished is both necessary and sufficient to establish that it is permissible for us to do so. In contrast, a less strict form of deontological theory that is open to a wider range of factors in evaluating punishment could, in principle, draw on punishment's net social costs in determining how much punishment is enough. ${ }^{49}$

Of course, it is always possible to imagine that there are further, strictly deontological, constraints that would permit a deontological theory of punishment to be appropriately critical of mass incarceration. However, while Wellman's example of third-party promises of immunity may be probative in individual contexts, it seems unlikely to explain why the United States has unjustly incarcerated hundreds of thousands, if not millions, of people over the last several decades. ${ }^{50}$ So we need some other deontological constraint to explain why, given that millions of people have forfeited their rights by committing crimes, we are

\footnotetext{
48 Supra note 7, p. 375 n. 7.

${ }^{49}$ For a contemporary exemplar of such a view, see Mitchell N. Berman, "Punishment and Justification," Ethics 118 (2008): pp. 258-290.

${ }^{50}$ As it happens, there is a legal device that operationalizes roughly the kind of promise Wellman envisions, which is a prosecutor's offer of immunity in exchange, for example, for cooperation with an ongoing investigation. It is unlikely that the United States incarcerates too many people because too many of these promises have been reneged on.
} 
nevertheless obligated to punish only a small fraction of them. Given the inadequacy of standard deontological constraints on punishment to explain what is wrong with mass incarceration, it hardly seems unfair to shift the burden onto deontological theorists to state what those further conditions are supposed to be. These further conditions should explain why the United States today, despite punishing only a small fraction of the guilty, nevertheless punishes too many people. These conditions should not surreptitiously introducing the very aggregative reasons that strict deontology is committed to excluding as irrelevant.

Finally, it might be objected that even, if the United States does not incarcerate too many people, a deontological theorist can still explain why its criminal justice system is unjust in many other respects.

I am happy to concede this point. After all, I am not suggesting that deontological theorists cannot explain why American criminal justice institutions are unjust in any respect. There are lots of reasons why those institutions are unjust, and many of these reasons have little or nothing to do with the scale of those institutions-for instance, that the institutions are discriminatory, or that the conditions of confinement are unjustifiably harsh. Perhaps there are plausible deontological accounts of the rights that are violated by this kind of treatment. My interest here is with the narrow question of whether these institutions are unjust because they incarcerate too many people, setting aside the issue of whether they might also be unjust for other reasons. I should note, however, that the concern with the scale of criminal justice does have implications for at least some of these issues. Thus, suppose that American criminal justice institutions are unjust because the custodial population is disproportionately comprised of racial minorities. Whether you believe that justice requires this discrimination to be remedied by incarcerating fewer guilty minority defendants, or instead incarcerating more guilty white defendants, is sensitive to whether you accept a deontological theory of punishment.

4.

Absent a more complete account of the deontological constraints that limit the degree to which a society may permissibly punish the guilty, punishment theorists face a choice: either they can endorse the claim that the United States unjustly incarcerates too many people, or they can endorse a strictly deontological theory of punishment. What they cannot do is endorse both.

It is worth taking a step back to consider why it is that strictly deontological theories are unable to provide a plausible answer to how committed a society should be to punishing the guilty. The basic problem is, as I have put it, that they provide no principle for distinguishing between the first and the $n^{\text {th }}$ criminal: whatever reason (or permission) we have for punishing the first person applies equally to the $n^{\text {th }}$ person. That alone might not be such a problem. It becomes a problem, however, in the context of a theory that treats those reasons as sufficient to make punishment permissible. What drives the thought that such reasons are sufficient-that, for instance, the fact that A stole B's kidney is sufficient to justify the state in incarcerating A? What explains the intuition that there could be nothing unjust about incarcerating someone who is, in fact, guilty is the assumption that criminal 
punishment is simply the exemplification of an exclusively individualistic conception of wrongdoing and punishment. ${ }^{51}$

Seen from this perspective-what I have elsewhere referred to as a "private right conception" of the criminal law-criminal justice institutions are importantly distinct from the institutions and policies that regulate public health, education, income, the environment and so on. ${ }^{52}$ After all, for most political liberals, just policy in those contexts is not typically considered to be fully analyzable in terms of pre-institutional, individual desert. Rather, what someone deserves, e.g., by way of health care or income, depends upon the legitimate expectations engendered by just political institutions. This is not to say that pre-legal and individualistic reasons are excluded from consideration, but only that whether they give rise to a claim of justice depends on how they are taken up by just political institutions. For instance, suppose Jones would suffer unless he is provided with an extremely expensive drug. It is surely the case that Jones' suffering provides a reason in favor of providing him with that drug. But that alone is insufficient to show that he has a legal entitlement to subsidized access to the drug that any just state must necessarily honor. ${ }^{53}$ Whether Jones has a legal entitlement to the drug depends upon what a range of economic and political factors, such as the cost of ensuring that everyone in Jones' position receives the drug, as well as a fair and informed procedure for making a collective decision about such matters. ${ }^{54}$

The exclusive focus in strictly deontological theories on individual wrongdoing and punishment reverses the order of explanation. It suggests that criminal punishment institutions are just insofar as they give people what they deserve. This makes individual, pre-legal desert explanatory of the just distribution of punishment in a way that it is not for other socially created and allocated goods. For those goods, what you deserve is explained by what just institutions do; when it comes to punishment, what just institutions do is explained by what you deserve (or, at least, what you do not deserve.)

What makes individualism seem attractive as a view of criminal punishment is the thought that criminal punishment is simply private punishment as carried out by the state in lieu of private parties. The everyday morality of punishment—as between friends, family members and colleagues-generally does not raise large questions of fair distribution and social cost. Instead, as between private parties, what is paramount is the felt need to manifest our moral convictions by punishing the wicked. This assimilation of punishment

\footnotetext{
51 This, I suspect, is what gives Wellman's kidney example its force: taken individually, each of the kidney thieves morally deserves punishment. Does that necessarily make it permissible to give it to them? All of them?

52 See Vincent Chiao, "Two Conceptions of the Criminal Law," in Chad Flanders and Zach Hoskins (eds.), The New Philosophy of Criminal Law (forthcoming).

53 The thought that Jones does have an entitlement to the treatment that any legitimate state must honor is, of course, simply a fancy way of putting Sarah Palin's infamous "death panels" objection to public health insurance: people have rights (to health care), and there are things no state can do to them (such as deny them that care) without violating their rights.

54 The thought that punishment must be deserved, and that desert (at least in this context) must be individualistic, has deep roots. For an enlightening discussion, see Samuel Scheffler, "Justice and Desert in Liberal Theory," California Law Review 88 (2000): pp. 983-987.
} 
of individuals to punishment as a social institution renders strictly deontological theories exemplars of what Robert Nozick described as "unpatterned" theories of justice. Any pattern of outcomes in the aggregate is just so long as it results from a series of transactions that are individually just. For instance, any pattern of overall incarcerationany value for $n_{\text {MAX }}$ - is just, so long as it results from proportionate punishment of the guilty. And, hence, the source of the problem: the judgment that the United States now incarcerates too many people is, like the judgment that income inequality is too high, a judgment about an aggregate pattern of outcomes. It is not a judgment about the quality of the individual transactions that lead to that result.

We are now in a position to draw several more constructive lessons. The first is that, before endorsing a theory of punishment, we should apply its principles to actually existing institutions to see if it returns equally plausible results at the institutional level as it does in cases of individual wrongdoing. This test is motivated by the thought that a theory of punishment is more than simply a theory of interpersonal morality writ large; it is a theory that is meant to evaluate large and highly coercive institutions that affect entire populations in complex, and sometimes contradictory, ways.

Second, if the pattern of American-style mass incarceration is indeed objectionable, then we should further insist that a theory of punishment evaluate not simply how a resulting pattern of punishment outcomes was arrived at, but the value of this or that pattern. A theory of punishment should be at least partially patterned, and the pattern it defends should rest on a substantive account of the point of incarcerating this or that many people.

Third, in specifying the nature of that value, an adequate theory of punishment will almost certainly have to accept that the aggregate costs and benefits of an institution of punishment are relevant to its justification. Sensitivity to the social costs of punishment provides a means for a theory of punishment to distinguish between the first and the $n^{\text {th }}$ wrongdoer, and hence to decide how committed to punishing the guilty a society should be.

Of course, to say that aggregative concerns are relevant to permissibility is not to say that they determine it. So-called "hybrid" or "side-constrained" approaches to punishment are consistent with endorsing principles that apply directly to overall patterns of punishment outcomes, even while they insist that even just patterns of punishment only be reached through means that respect rights. In short, to satisfy this criterion of adequacy requires a theory of punishment to not simply set constraints on the use of criminal punishment, but also to articulate a plausible target towards which criminal punishment is oriented, and against which the operation of actual institutions can be evaluated as more or less adequate.

This way of putting the matter may make it seem as if only a utilitarian theory of punishment-one that holds that punishment is justified up to the point where the marginal cost of an additional unit of punishment exceeds the marginal gains-would meet the minimal criterion. But this is a plain non sequitur. There are many ways of specifying a target, and the specific approach of classical utilitarianism-maximizing aggregate welfare or preference satisfaction-is but one of them. ${ }^{55}$

55 Pettit and Braithwaite's republican theory of punishment, for instance, is expressly consequentialist but not at all utilitarian. See John Braithwaite and Philip Pettit, Not Just Deserts: $A$ Republican Theory of Criminal Justice (Oxford: Oxford University Press, 1987). 
Consider a more explicitly political interpretation of what is required to satisfy these minimal criteria. Perhaps what it is for an individual to be fairly treated by the criminal justice system should not be explained in purely individualistic terms, but should be assessed against the legitimate expectations engendered by institutions that operate according to publicly avowable principles of justice. Plausibly, institutions that meet this standard will provide an adequate level of protection to a range of basic interests on a nondiscriminatory and non-hierarchical basis, but not so much protection as to prevent the effective delivery of other crucial services, such as health care, education and so forth, given both resource scarcity as well as the impact of punishment itself on those interests. Just as how much of her income a person "deserves" to keep, or how much health care she "deserves" to receive should she fall ill are determined by reference to the costs to others of adopting the corresponding policy, what a person "deserves" by way of punishment is determined by considering whether others could reasonably be expected to bear the costs of imposing it upon her. But because criminal punishment itself invades basic interests, there is a strong reason not to have more of it than necessary-that is, more than necessary to maximally protect basic interests in a non-discriminatory and non-hierarchical basis. A political theory of punishment of this form meets the minimal criterion of adequacy without collapsing into a form of utilitarianism: it provides a general framework for evaluating when criminal punishment is just or unjust in a way that is sensitive to the aggregate social costs of punishment, but under a substantively different set of principles from those espoused by classical utilitarianism.

The range of possible evaluative standards, from more to less egalitarian, and more to less democratic, is obviously manifold, and I do not intend here to even begin to address the complex questions required to fully defend any one of them. One possible-and, to my mind, attractive-way of fleshing out the publicly avowable principles of justice is in largely prioritarian terms, where a particularly salient question is the impact of penal institutions on the fair distribution of effective access to basic capabilities. A capability is basic if it is required in that society to live as an equal-as a peer among peers. Because of how essential these capabilities are to a person's equal standing in society, those whose lives are thereby affected by the operation of criminal justice institutions-for instance, because they are incarcerated, or because they are exposed to a risk of serious victimization-are owed an explanation of why they ought to agree to have their lives affected in that way. Moreover, the explanation should be couched in terms that everyone can reasonably be expected to accept. Since incarceration will certainly invade effective access to a wide swath of basic capabilities, it is not enough to show that the legal rule which they are used to enforce is designed to protect basic capability; it must also be shown that the reliance on custodial sanctions to this or that degree is reasonably required to maximize effective access to basic capabilities for all, with priority given for the worst off.

No normative theory of criminal justice, including this one, should be expected to generate unique and determinate answers to detailed questions about this or that policy initiative. However, it should at least provide a plausible framework for deciding whether a society is made better or worse off when it quintuples the size of its incarcerated population in the space of a single generation, even assuming that every single person who cycles through those institutions is clearly guilty of an uncontroversial crime, and serves an unambiguously proportionate sentence under entirely reasonable conditions. In contrast to deontological theories, the prioritarian approach I have sketched at least suggests $a$ 
principle, if no doubt contestable in application, for addressing these kinds of questions. If it turns out that quintupling the size of the custodial population does not maximize the likelihood that everyone-including those held in custody-has effective access to basic capability when compared to other reasonably feasible institutional arrangements, that would be a reason not to do so, and potentially a reason to undo it if has already been done.

A normative theory of criminal justice that takes seriously the aggregate costs and benefits of those institutions, as well as how those costs and benefits are distributed across a population, cannot afford to be as austerely abstract as deontological theories tend to be. Deontological theories of punishment can hardly be faulted for being uniquely immune to facts, but their resistance to empirical confirmation or falsification is consistent with a moralizing approach to the criminal law that actively rejects detailed policy analysis for sweeping expressions of moral sentiment. I will simply note that California's notorious "three strikes" law, which is both harsher and broader than habitual offender laws in other states, was initially drafted by the father of a murder victim, and gained political traction after a paroled repeat violent offender kidnapped, sexually assaulted and murdered a twelve-year-old girl. It was precisely not the product of any kind of careful, cold-blooded look at the costs of enacting a three strikes law. Indeed, later efforts merely to fund a study of the law's impact were vetoed by the governor. Why bother? After all, if we are entitled to punish wrongdoers regardless of (as Duff puts it) the "contingent future benefits" from doing so, and regardless of (as Wellman puts it) whether doing so is "necessary to promote some important aim," then evidence about what good punishment achieves is simply beside the point.

This suggests a final criterion of adequacy. A plausible theory of punishment must be sensitive to the empirical evidence about the conditions under which we should expect punishment in general, and custodial sanctions in particular, to be an effective means in achieving those ends. The evaluation of these conditions should therefore take into account the range of feasible alternatives for achieving those ends. ${ }^{56}$ The evidence amassed by be sociologists, economists and criminologists about the extraordinarily high net social costs of mass incarceration is evidence that a theory of punishment, if it is to provide plausible

\footnotetext{
56 For just one example, a theory of punishment that takes seriously the task of determining when the use of custodial sanctions is appropriate, and when it has become excessive, must be sensitive to what we know about how people respond to the possibility of sanction. See, for instance, William Spelman, "What Recent Studies Do (and Don't) Tell Us About Imprisonment and Crime", Crime \& Justice 27 (2000): pp. 419-494; Redburn, Travis, and Western, supra note 2, Chapter 5. Naturally, what we conclude from an estimate of the elasticity of crime to punishment depends in part upon broader commitments in the theory of justice-how we assess the social value of reducing crime as against the costs of punishment, as well as how we assess the resulting distribution of social advantage across the population. The need for an overarching normative theory is apparent when considering that punishment is not the only way to reduce criminal offending; other means, such as increasing the male high school graduation rate, also appear to reduce offending, though at different rates, and with a different distribution of social costs and benefits. See Lance Lochner and Enrico Moretti, "The Effect of Education on Crime: Evidence from Prison Inmates, Arrests and SelfReports", American Economics Review 94 (2004): pp. 155-189.
} 
guidance for real-life criminal justice institutions, must take seriously. It need not treat such information as decisive, but it cannot afford to completely ignore it, either. ${ }^{57}$

\section{5.}

There is a fair amount of irony to the argument I have mounted. Consequentialist theories of punishment are often thought to be unprincipled because they are allegedly consistent with excessive punishment and the trampling of people's rights in the name of crime reduction. The irony is that it is actually strictly deontological theories that lack the resources to constrain the growth of the carceral state. Despite their emphasis on constraining punishment, in practice it is strictly deontological theories that turn out to have a problem with punishment maximalism. Refusing to so much as consider punishment's "contingent future benefits" or its contribution to an "important social aim" may appear principled in the context of the individual case, but it is much more problematic when used as a justification for ignoring the aggregate impact of hundreds of thousands, or even millions, of identical punitive decisions. Ignoring aggregation in this broader context yields the result that where the net social costs of a generalized practice are steeply rising, the fact that they are not obviously decisive in the individual case will mask quite extreme costs when generalized to social policy, costs that no one would think it reasonable to incur if presented with the policy in the aggregate. Yet because of their systematic exclusion of social cost, this is precisely what strictly deontological theories entail.

When the aggregate costs of incarceration are worth bearing, and when they are notas well as what it is to share in bearing those costs as political equals-are questions that cannot answered simply by observing that a penal system only punishes the guilty, and then only proportionately. It requires instead a theory that takes seriously the political character of criminal justice institutions, and especially their role as public institutions that create and allocate crucial forms of social advantage. What is unjust about mass incarceration is not that it necessarily tramples individual rights. It is that it seriously, and all too often permanently, disfigures millions of lives for little to no end, and thereby imposes extraordinary costs on people in a way that is inconsistent with publicly avowable principles of justice. Hence, if it is to be both satiable and relevant to the design of public institutions, a theory of punishment should start with a conception of criminal punishment as the subject matter of a political theory of justice, rather than simply private morality writ large.

\footnotetext{
57 Franklin Zimring, Gordon Hawkins, and Sam Kamin archly noted that popular support for the law "could be the opposite of an instrumental justification, in which people believe that the legislation is appropriate only because it is effective. Instead, it is often the case that belief in the effectiveness of a penal statute is rooted in the citizens' conviction that the law is appropriate. Since the penal measures feel right, they must be working well." Zimring, Hawkins, and Kamin, supra note 40, p.
} 221. 